\title{
Infections of Unicauda clavicauda (Kudo, 1934) (Myxozoa) in the skin of Notropis hudsonius (Cyprinidae) from Montana, with a synopsis of the genus Unicauda Davis, 1944
}

\author{
David K. Cone ${ }^{1}$ and Jason S. Melendy ${ }^{2}$ \\ ${ }^{1}$ Department of Biology, Saint Mary's University, Halifax, Nova Scotia, B3H 3C3, Canada; \\ ${ }^{2}$ Department of Biology, Dalhousie University, Halifax, Nova Scotia, B3H 4H3, Canada
}

Key words: Myxosporea, Unicauda clavicauda, Notropis hudsonius

\begin{abstract}
Infections of Unicauda clavicauda (Kudo, 1920) Davis, 1944 (Myxozoa) are described from Notropis hudsonius (Clinton) in Montana. Plasmodia form beneath scales of the body and produced spores within a loosely-defined matrix. Fixed spores are oval in front view, 11-14 $\mu \mathrm{m}$ long and 9-10.5 $\mu \mathrm{m}$ wide, and contain a posterior appendage that is up to $26 \mu \mathrm{m}$ long. The polar capsules are 4-6 $\mu \mathrm{m}$ long and 2.5-4 $\mu \mathrm{m}$ wide. The study represents the first report of $U$. clavicauda since the original species description and a new host and geographical record. The taxonomic history of Unicauda Davis, 1944 is summarised and it is concluded the following 10 species are valid members of the genus: U. aristichthydis Zhao et Ma, 1995, U. brachyura (Ward, 1919), U. caudatus (Gogebashvili, 1965), U. clavicauda, U. crassicauda (Kudo, 1934), U. lumae Rahemo, 1976, U. macrura (Gurley, 1893), U. magna Minchew, 1981, U. pelteobagrus Ma, 1998, and U. wuhanensis Xiao et Chen, 1993. All of these species have circular, subcircular, or oval spores in frontal view and all parasitise fish of the superorder Ostariophysi. As a group they are known from temperate freshwater locations in North America, Europe and Asia. A list of 16 species described or transferred to Unicauda at one time or another, but not recognised as members of the genus in the present study, is provided.
\end{abstract}

Species of Unicauda Davis, 1944 (Myxozoa) are histozoic myxobolids with a characteristic single appendage extending posteriorly from the fullydeveloped spore. The appendage is not an extension of the spore valves, but rather a structure made up of a different material and adhering to the shell valves along a distinct boundary (Lom and Noble 1984). The genus has a confused taxonomic history, with various species being transferred in and out of the taxon (Gupta and Khera 1987). What appear to be valid members of the genus have been reported from freshwater fishes in North America (Gurley 1893, 1894, Ward 1919, Davis 1922, Kudo 1934, Meglitsch 1937, Minchew 1981), Europe (Alvarez-Pellitero and Gonzalez-Lanza 1985), Iraq (Rahemo 1976), Georgia, former USSR (Gogebashvili 1966), and China (Chen and Ma 1998). However, these species are, for the most part, poorly described and the majority of them have not been reported since the original descriptions.

The present study provides new information on Unicauda clavicauda (Kudo, 1934) Davis, 1944 parasitising spottail shiner Notropis hudsonius (Clinton) in Montana, and reviews the somewhat chequered taxonomic history of Unicauda.

\section{MATERIALS AND METHODS}

Five infected spottail shiner were collected from Timber Reservoir, Montana, June 9, 1993, and preserved in 10\% buffered formalin. Temporary wet mounts in $1 \%$ molten agar were prepared and used to examine spores. Photographs of selected fixed, stabilised spores were made from Kodak TMax 100 film developed by recommended procedures. Histological sections of infected tissue were prepared using standard methods and stained with Giemsa stain. Voucher slides are deposited in the U.S. National Parasite Collection (Accession No. 090041.00), Beltsville, Maryland. All reported measurements are in micrometres unless stated otherwise.

\section{RESULTS}

The body flanks of all five shiners were covered with ovoid, white cysts measuring up to $1 \mathrm{~mm}$ in length and having a coarsely crenulated margin. Sections revealed that plasmodia developed immediately beneath, and abutted directly against, the underside of scales (Fig. 1). The epidermis overlying infected scales was lifted or detached, and often the posterior margin of the scale was raised. In every case examined, the plasmodia did not extend beyond the edge of the scale.

Plasmodia were comprised of a thin, faintly staining ectoplasm and an internal endoplasm comprised of a loosely defined matrix containing developed spores throughout. Fixed spores were subcircular in frontal view (Figs. 2, 3) and measured 11-14 $\mu \mathrm{m}$ (mean $12.3 \pm$ $0.7, \mathrm{n}=15)$ long and 9-10.5 $\mu \mathrm{m}(10.1 \pm 0.7, \mathrm{n}=14)$ wide. They had a width-to-length ratio of $1: 1.2 \pm 0.08$. The two polar capsules were similar in size, pyriform, 4-6 $\mu \mathrm{m}(5.1 \pm 0.4, \mathrm{n}=14)$ long, $2.5-4.0 \mu \mathrm{m}(3.0 \pm 0.6$, $\mathrm{n}=15)$ wide, and usually converged at their apex. 


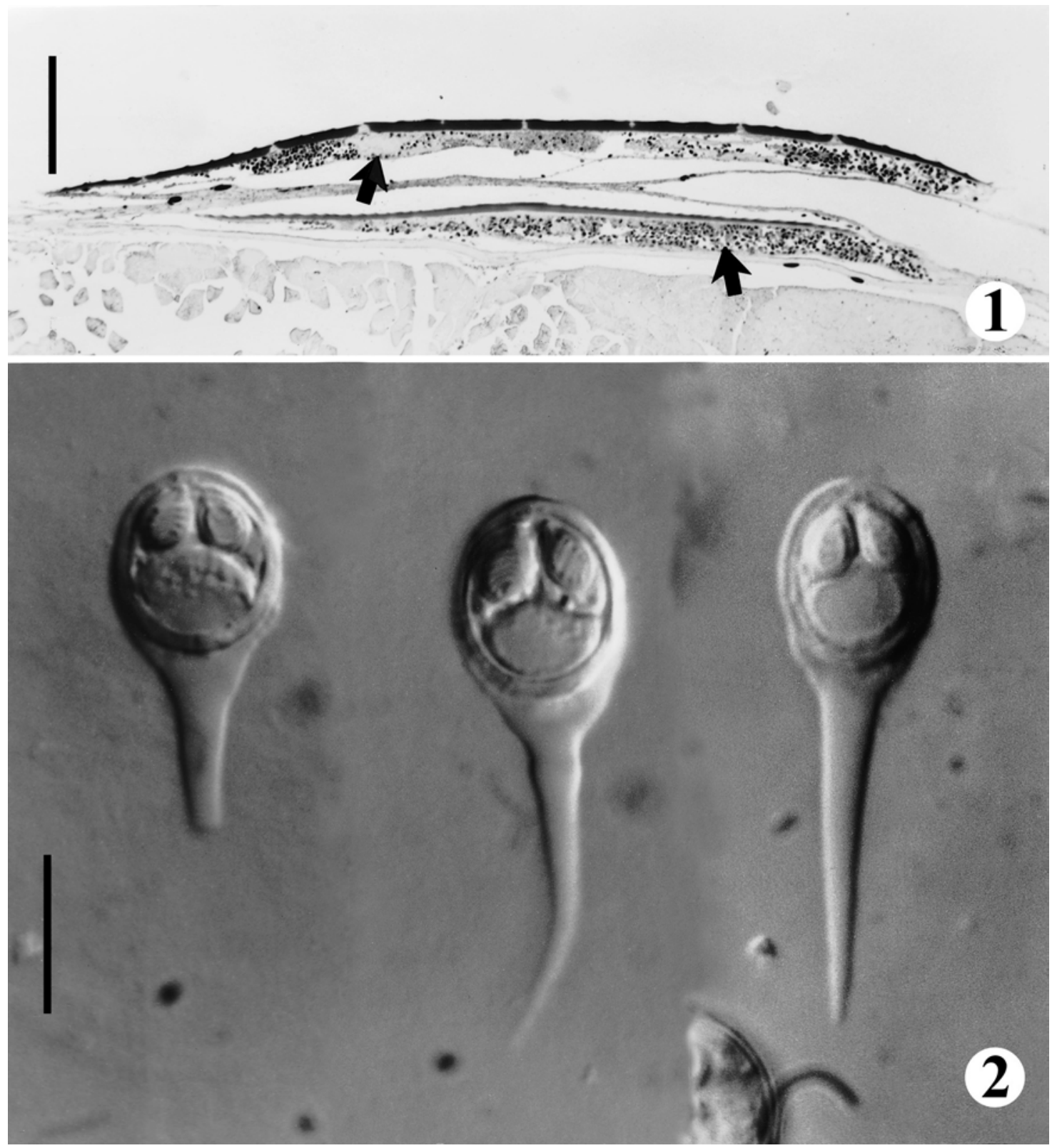

Fig. 1. Histological section of plasmodia (arrows) of Unicauda clavicauda situated immediately beneath dermal scales of Notropis hudsonius. Fig. 2. Fixed spores of U. clavicauda. Scale bars: Fig. $1=100 \mu \mathrm{m}$; Fig. $2=10 \mu \mathrm{m}$.

However, in some spores, the tapered ends diverged from the longitudinal axis of the capsule to run parallel toward the exit pores. A round to bean-shaped sporoplasm filled the post-capsular region of the spore and there were 3-5 sutural ridge folds. There was no obvious intercapsular appendix and a iodinophilous vacuole was not detected in the spores.

The spore appendage was straight or curved slightly to one side of the longitudinal axis (Figs. 2, 3) and measured 5.5-26 $\mu \mathrm{m}(17.4 \pm 5.2, \mathrm{n}=15)$ long. It abutted the valves in a cup-shaped fashion and gradually tapered distally, sometimes with 3 or 4 annular constrictions occurring evenly along its length. Developing spores had no evidence of an appendage. Spores with a short, and presumably forming appendage, had a blunt terminal end but no hint of any external cellular structure that could be linked with its formation. Long appendages had a pointed terminal end.

\section{DISCUSSION}

Unicauda clavicauda (Kudo, 1934) Davis, 1944 was originally described from the straw-coloured minnow Notropis blennius in the Rock River, Illinois (Kudo 


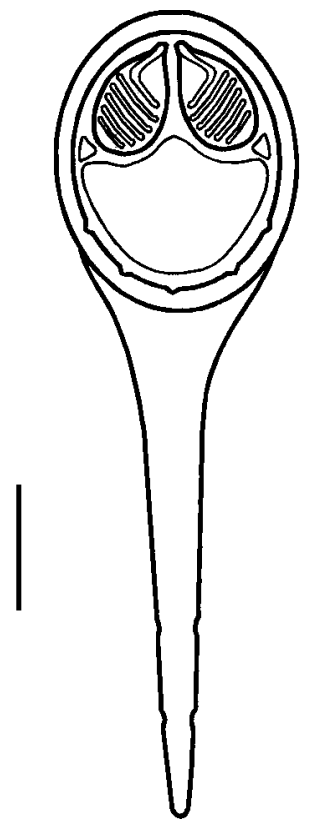

Fig. 3. Drawing of spore of Unicauda clavicauda. Scale bar $=$ $5 \mu \mathrm{m}$.

1934). The present report is a new host and geographical record and the first since the original species description.

Kudo (1934) considered $U$. clavicauda to have several diagnostic features. The spores are subcircular in frontal view with an appendage measuring 20-30 $\mu \mathrm{m}$ and having annular constrictions and a pointed tip. The polar capsules have a narrow tubular region that run parallel to each other before reaching the exit pores. These features varied somewhat in the new material. For example, spores were identical in shape but slightly larger in size and the aligned exit tubes were seen in some but not all spores. Similarly, the appendage was often blunt, not always pointed, and not necessarily with annular constrictions. Gurley (1894) noted that the annular constrictions varied with the type of fixative used.

There are four other confirmed members of the genus known from freshwater fishes in North America (Table 1). All form histozoic plasmodia in skin tissue and all have subcircular spores in frontal view. Spores of $U$. clavicauda are smaller than those of $U$. magna but similar in size to those of $U$. crassicauda (Table 1). The appendage in $U$. clavicauda is significantly shorter than those of U. macrura, U. magna, and U. crassicauda, but longer in maximum length than that of $U$. brachyura. (Table 1). Both $U$. macrura and $U$. brachyura have spores that are apparently narrower than those of $U$. clavicauda (Table 1). All measurements of spores of these species are based on fixed material.

Unicauda clavicauda was originally reported from plasmodia in subdermal connective tissue of the body and fins. The cysts we found occurred in loose connective tissue of the scale pockets above the dermis, abutting the underside of scales. The species clearly has an affinity for connective tissue associated with dermal scales and in this regard resembles other scale-dwelling myxosporeans such as Myxobolus notemigoni Lewis et Summerfelt, 1964, Myxobolus squamaphilus Molnár, 1997, and Myxobolus episquamalis Egusa, Maeno et Sorimachi, 1997. However, in each case, the myxosporean has a unique association with the host scale. For example, plasmodia of $M$. notemigoni occur immediately beneath the scales of Notemigonus crysoleucas and adhere directly to them (Lewis and Summerfelt 1964) similar to that found with $U$. clavicauda. Myxobolus episquamalis forms large, flat cysts on the surface of the scales of Mugil cephalus, with plasmodia taking on branched hyphal-like forms that liquefy and penetrate scales (Egusa et al. 1990). In contrast, M. squamaphilus forms small, lentil-shaped plasmodia on the surface of the scales of Abramis brama, with no penetration (Molnár 1997). Whatever the specific association with the host scale, all of the mentioned species develop at a site convenient for immediate dispersal of spores away from the host. For M. squamaphilus, such release has been observed in the late spring with no report of host mortality (Molnár 1997).

The compositional makeup of the appendage of Unicauda has not been characterised to date. We know it dissolves in hydrochloric acid, stains rose-red or pink with Giemsa and with Delafield hematoxylin, stains blue-grey with Lugol's iodine, and is rendered invisible in balsam-mounted histological sections (Kudo 1934, Minchew 1981). The appendage resembles most closely the two, rigid appendages of Dicauda Hoffman et Walker, 1978, which are thought to be modified mucous envelopes present in various degrees of development in other myxobolids (Hoffman and Walker 1978). How the appendages are formed into specific shapes and sizes remains a mystery. We do know that they form after development of the spore.

Davis (1944) proposed the genus to accommodate henneguyid-like species with a single caudal extension of the spore. The genus was considered a junior synonym of Henneguya Thélohan, 1832 by Shulman $(1966,1984)$ but has been accepted by most authors as valid (Tripathi 1952, Wyatt 1979, Lom and Dyková 1992, Gupta and Khera 1987, Chen and Ma 1998, Hoffman 1999) given the obvious lack of homology between appendages in spores of the two taxa.

We have examined descriptions of 26 nominal species that have at one time or another been assigned to Unicauda and conclude that only 10 of these can be considered valid members of the genus. In each case, the appendage is clearly noted as being a single, separate entity from the spore valves. These species include: 
1. U. aristichthydis Zhao et Ma, 1995 from Aristichthys nobilis (Cypriniformes) in China (see Chen and Ma 1998);

2. U. brachyura (Ward, 1919) Davis, 1944 from Notropis anogenus (Cypriniformes) in Lake Erie, U.S.A. (Ward 1919);

3. U. caudatus (Gogebashvili, 1965) Landsberg et Lom, 1991 (syn. Myxobolus catanei Pellitero et Gonzalez-Lanza, 1985) from Barbus lacerata cyri (Cypriniformes) in the Krura River, Georgia, in the former U.S.S.R. (Gogebashvili 1966) and from Barbus barbus bocagei in River Esla, Spain (Alvarez-Pellitero and Gonzalez-Lanza 1985);

4. U. clavicauda (Kudo, 1934) Davis, 1944 from Notropis blennius (Cypriniformes) in Illinois, U.S.A. (Kudo 1934) and Notropis hudsonius in Montana, U.S.A. (present study);

5. U. crassicauda (Kudo, 1934) Davis, 1944 from Campostoma anomalum (Cypriniformes) in Illinois, U.S.A. (Kudo 1934);

6. U. lumae Rahemo, 1976 from Barbus grypus (Cypriniformes) in River Tigris, Iraq (Rahemo 1976);

7. U. macrura (Gurley, 1893) Davis, 1944 from Hybognathus nuchalis (Cypriniformes) in Texas, U.S.A. (Gurley 1893);

8. U. magna Minchew, 1981 from Pimephales promelas (Cypriniformes) in Pennsylvania, U.S.A. (Minchew 1981);

9. U. pelteobagrus Ma, 1998 from Pelteobagrus fulvidraco, $P$. vachelli, and P. nitigus (Siluriformes) in Sichuan Province, China (Chen and Ma 1998);

10. U. wuhanensis Xiao et Chen, 1993 from Carassius auratus gibelio (Cypriniformes) in China (see Chen and Ma 1998).

Interestingly, in each case, spores are circular, subcircular, or oval in frontal view and hosts involved are members of the superorder Ostariophysi. It appears that the lineage Unicauda has had a long evolutionary history with these freshwater fishes, with current distributions extending throughout temperate regions of the Northern hemisphere, including North America, Europe and Asia. The parasites described to date are host specific within separate fish genera.

The report of Unicauda sp. from P. promelas in northwest Iowa (Krall et al. 1982, Mitchell et al. 1983) appears to have involved U. magna. The report of $U$. crassicauda from Ptychocheilus orgonensis in British Columbia (Arai and Mudry 1983) must be confirmed since a description of spores was not provided.

The remaining 16 species are considered questionable members of the genus because of lack of detail about the appendage. These include:

1. U. armati Gupta et Khera, 1987 from Mastacembelus armatus (Synbrachiformes) in Punjab, India (Gupta and Khera 1987);

2. U. andhrae Kalavati et Narasimhamurti, 1981 from Ophicephalus gachua (Perciformes) Anantagiri, India (Kalavati and Narasimhamurti 1981);

3. U. basiri Bhatt et Siddiqui, 1964 from Ophicephalus punctatus (Perciformes) in Aligarh, India (Bhatt and Siddiqui 1964);

4. U. bengalensis Chaudhuri et Chakravarty, 1970 from O. punctatus in Naihati, India (Chaudhuri and Chakravarty 1970);

5. U. bicornuata Chaudhuri et Chakravarty, 1970 from O. punctatus in Calcutta, India (Chaudhuri and Chakravarty 1970);

6. U. carassii (Fujita, 1924) Davis, 1944 from Carassius vulgaris (Cypriniformes) in Okayama, Japan (Fujita 1924);

7. U. chaudhuryi Bajpai et Haldar, 1982 from Ophicephalus punctatus in West Bengal, India (Bajpai and Haldar 1982a);

Table 1. Summary of morphological characteristics reported for confirmed species of Unicauda Davis, 1944 reported from host fishes in North America.

\begin{tabular}{|c|c|c|c|c|c|c|}
\hline & U. brachyura & U. clavicauda & U. clavicauda & U. crassicauda & U. macrura & U. magna \\
\hline Spore length & $10-11.5$ & $10-11.5$ & $11-14$ & $12-14.5$ & $10-11$ & $14-17$ \\
\hline Spore width & $8-8.8$ & $9.5-9.5$ & $9-10.5$ & $8.5-10.5$ & $6-8$ & $12-14.5$ \\
\hline Spore thickness & $4-5$ & 6 & - & $6-7$ & 4 & - \\
\hline $\begin{array}{l}\text { Polar capsule } \\
\text { length }\end{array}$ & $3-4$ & $5-5.5$ & $4-6$ & $5-6$ & - & $7.5-9.5$ \\
\hline $\begin{array}{l}\text { Polar capsule } \\
\text { width }\end{array}$ & 2 & 2.5 & $2.5-4$ & $3-3.5$ & - & $3.0-5.0$ \\
\hline $\begin{array}{l}\text { Appendage } \\
\text { length }\end{array}$ & up to 17 & $20-30$ & up to 26 & $40-55$ & $30-40$ & $60-154$ \\
\hline Host species & $\begin{array}{l}\text { Notropis } \\
\text { anogenus }\end{array}$ & $\begin{array}{l}\text { Notropis } \\
\text { blennius }\end{array}$ & $\begin{array}{l}\text { Notropis } \\
\text { hudsonius }\end{array}$ & $\begin{array}{l}\text { Campostoma } \\
\text { anomalum }\end{array}$ & $\begin{array}{l}\text { Hybognathus } \\
\text { nuchalis }\end{array}$ & $\begin{array}{l}\text { Pimephales } \\
\text { promelas }\end{array}$ \\
\hline Tissue site & $\begin{array}{l}\text { Cartilaginous } \\
\text { fin rays }\end{array}$ & $\begin{array}{l}\text { Subdermal } \\
\text { connective } \\
\text { tissue }\end{array}$ & $\begin{array}{l}\text { Subdermal } \\
\text { connective } \\
\text { tissue }\end{array}$ & $\begin{array}{l}\text { Subcutaneous } \\
\text { connective } \\
\text { tissue }\end{array}$ & $\begin{array}{l}\text { Subdermal } \\
\text { connective } \\
\text { tissue }\end{array}$ & Fins \\
\hline Locality & Lake Erie & Illinois & Montana & Illinois & Texas & Pennsylvania \\
\hline Reference & Ward (1919) & Kudo (1934) & Present study & Kudo (1934) & Gurley (1893) & Minchew (1981) \\
\hline
\end{tabular}


8. U. fontinalis (Fantham, Porter et Richardson, 1939) Davis, 1944 from Salvelinus fontinalis (Salmoniformes) in Quebec, Canada (Fantham et al. 1939, Fantham and Porter 1948);

9. U. limatula (Meglitsch, 1937) Tripathi, 1952 from Ictalurus punctatus and I. furcatus (Siluriformes) in Ohio, U.S.A. (Meglitsch 1937);

10. U. monera (Gurley, 1893) Davis, 1944 from Aphredoderus sayanus (Percopsiformes) in New Jersey, U.S.A. (Gurley 1893, 1894);

11. U. ophicephali (Chakravarty, 1939) Tripathi, 1952 from Ophicephalus gachua (Perciformes) in Calcutta, India (Chakravarty 1939);

12. U. plasmodia (Davis, 1922) Davis, 1944 from Ictalurus punctatus (Siluriformes) in Iowa, U.S.A. (Davis 1922);
13. U. ritae Bajpai et Haldar, 1982 from Rita rita (Siluriformes) in West Bengal, India (Bajpai and Haldar, 1982b);

14. U. spatulata (Fujita, 1924) Davis, 1944 from Carassius vulgaris (Cypriniformes) in Fukoka and Shimane, Japan (Fujita 1924);

15. U. strongylura (Gurley, 1893) Davis, 1944 from Synodontis schal (Siluriformes) in the Nile River, Egypt (Gurley 1893, 1894);

16. U. xihuensis $\mathrm{Wu}$ et $\mathrm{Li}, 1986$ from Carassius carassius cuvieri (Cypriniformes) in Hangzhou, China (Wu and Li 1986).

Acknowledgements. This work was funded by an NSERC Research Grant awarded to D.K.C. The authors thank G. L. Hoffman for bringing the case history to their attention and for R. Peterson for making the original collection of fish.

\section{REFERENCES}

ALVAREZ-PELLITERO M.P., GONZALEZ-LANZA M.C 1985: Studies on Myxobolus spp. of Barbus barbus bocagei from the river Esla (León, NW Spain). Angew. Parasitol. 26: 3-12.

ARAI H.P., MUDRY D.R. 1983: Protozoan and metazoan parasites of fishes from the headwaters of the Parsnip and McGregor rivers, British Columbia: a study of possible parasite transfaunations. Can. J. Fish. Aquat. Sci. 40: 1676-1684.

BAJPAI R.R.N., HALDAR D.P. 1982a: A new myxosporidan, Unicauda chaudhuryi n. sp. (Myxozoa: Myxosporea) from the fish, Ophicephalus punctatus Block. Riv. Parassitol. 43: 147-152.

BAJPAI R.R.N., HALDAR D.P. 1982b: Observations on a new species of Unicauda Davis, 1944 (Myxozoa: Myxosporea) from the teleost, Rita rita Hamilton. Arch. Protistenkd. 125: 79-86.

BHATT V.S., SIDDIQUI W.A. 1964: Four new species of Myxosporidia from the Indian freshwater fish Ophicephalus punctatus Bloch. J. Protozool. 11: 314-316.

CHAKRAVARTY M.M. 1939: Studies on Myxosporidia from the fishes of Bengal, with a note on the myxosporidian infections in aquaria fishes. Arch. Protistenkd. 92: 169-178.

CHAUDHURI S.R., CHAKRAVARTY M.M. 1970: Studies on Myxosporidia (Protozoa, Sporozoa) from the food fishes of Bengal. I. Three new species from Ophicephalus punctatus Bloch. Acta Protozool. 8: 167-173.

CHEN C., MA C. 1998: Fauna Sinica. Myxozoa. Myxosporea. Science Press, Beijing, 993 pp.

DAVIS H.S. 1922: A new myxosporidian parasite of the channel catfish, Ictalurus punctatus. J. Parasitol. 8: 118122.

DAVIS H.S. 1944: A review of the genus Henneguya (Myxosporidia) with descriptions of two new species. Trans. Am. Microsc. Soc. 63: 311-320.

EGUSA S., MAENO Y., SORIMACHI M. 1990: A new species of Myxozoa, Myxobolus episquamalis sp. nov. infecting the scales of mullet, Mugil cephalus L. Fish Pathol. 25: 87-91.
FANTHAM H.B., PORTER A. 1948: The parasitic fauna of vertebrates in certain Canadian fresh waters, with some remarks on their ecology, structure and importance. Proc. Zool. Soc. Lond. Ser. B 117: 609-649.

FANTHAM H.B., PORTER A., RICHARDSON L.R. 1939: Some Myxosporidia found in certain freshwater fishes in Quebec Province, Canada. Parasitology 31: 1-77.

FUJITA T. 1924: Studies on Myxosporidian infection of the Crucian Carp. Jpn. J. Zool. 1: 45-57.

GOGEBASHVILI I.V. 1966: Parasitic protozoans of fish in the Kura River (within the boundaries of Georgia). Bull. Acad. Sci. Georgia 43: 465-472. (In Georgian.)

GUPTA S., KHERA S. 1987: On the genera Henneguya Thélohan, 1892 and Unicauda Davis, 1944. Res. Bull. Punjab Univ. 38: 153-163.

GURLEY R.R. 1893: On the classification of the Myxosporidia, a group of protozoan parasites infesting fishes. Bull. U. S. Fish. Comm. 11: 407-420.

GURLEY R.R. 1894: The Myxosporidia, or Psorosperms of fishes, and the epidemics produced by them. Part II. U. S. Comm. Fish and Fisheries. Report of The Commissioner for the year ending June 30, 1892: 65-304.

HOFFMAN G.L. 1999: Parasites of North American Freshwater Fishes. $2^{\text {nd }}$ Edition. Comstock Publishing, Cornell University Press, Ithaca, $539 \mathrm{pp}$.

HOFFMAN G.L., WALKER R. 1978: A new myxosporidan, Dicauda atherinoidi n. g., n. sp., of the minnow, Notropis atherinoides Rafinesque. J. Fish Dis. 1: 343-349.

KALAVATI C., NARASIMHAMURTI C.C. 1981: Unicauda andhrae n. sp. (Myxosporidia) in the mucus on the gills of Ophicephalus gachua. Z. Parasitenkd. 65: 89-93.

KRALL S.E., MITCHELL L.G., SEYMOUR C.L. 1982: Use of the plankton centrifuge in studies of population dynamics of myxozoan infections in fish. Proc. Iowa Acad. Sci. 89: 29.

KUDO R.R. 1934: Studies on some protozoan parasites of fishes of Illinois. Ill. Biol. Monogr. 23: 1-41.

LEWIS W.M., SUMMERFELT R.C. 1964: A myxosporidian, Myxobolus notemigoni sp. n., parasite of the golden shiner. J. Parasitol. 50: 386-389. 
LOM J., DYKOVÁ I. 1992: Protozoan Parasites of Fishes. Developments in Aquaculture and Fisheries Science, Vol. 26. Elsevier Publ., Amsterdam, 315 pp.

LOM J., NOBLE E.R. 1984: Revised classification of the class Myxosporea Bütschli, 1881. Folia Parasitol. 31: 193205.

MEGLITSCH P.A. 1937: On some new and known Myxosporidia of the fishes of Illinois. J. Parasitol. 23: 467-477.

MITCHELL L.G., KRALL S.C., SEYMOUR C.L. 1983: Use of the plankton centrifuge to diagnose and monitor prevalence of myxobolid infections in fathead minnows, Pimephales promelas Rafinesque. J. Fish Dis. 6: 379-384.

MINCHEW C.D. 1981: Unicauda magna sp. n. (Protozoa: Myxozoa): a new myxozoan from the fin tissues of the fathead minnow, Pimephales promelas Rafinesque. J. Fish Dis. 4: $513-518$.

MOLNÁR K. 1997: Myxobolus squamaphilus sp. n. (Myxozoa: Myxosporea), a common parasite of scales of bream (Abramis brama L.). Acta Protozool. 36: 221-226.

RAHEMO Z.I.F. 1976: Unicauda lumae sp. n. (Myxosporidia: Myxobolidae) from a fresh water fish, Barbus grypus Heckel, from River Tigris in Iraq. Z. Parasitenkd. 51: 1-5.

Received 16 September 1999
SHULMAN S.S. 1966: Myxosporidia of the Fauna of the USSR. Nauka, Moscow-Leningrad. Translated version published for the United States Department of the Interior and National Science Foundation, Amerind Publishing Co. Pvt. Ltd., New Delhi, India 1988, 631 pp.

SHULMAN S.S. 1984: Parasitic Protozoa. Vol. 1. In: O.N. Bauer (Ed.), Key to the Parasites of Freshwater Fauna of USSR. Nauka, Leningrad, 428 pp. (In Russian.)

TRIPATHI Y.R. 1952: Studies on parasites of Indian fishes. I. Protozoa Myxosporidia together with a check list of parasitic protozoa described from Indian fishes. Rec. Indian Mus. 50: 63-88.

WARD H.B. 1919: Notes on North American Myxosporidia. J. Parasitol. 6: 49-64.

WYATT E.J. 1979: Facieplatycauda pratti gen. n., sp. n. and two new species of Myxobolus (Myxosporidia). J. Protozool. 26: 47-51.

WU B., LI Z. 1986: Six new species of Myxosporidia from freshwater fishes in Zhejiang Province. Acta Zootaxon. Sin. 11: 1-7.

Accepted 27 April 2000 